\title{
The ISO 18.104: 2003 as Integrative Model of Nursing Terminologies
}

\author{
Marcia Regina Cubas ${ }^{1}$ \\ Adelita Gonzalez Martinez Denipote ${ }^{2}$ \\ Andreia Malucelli ${ }^{3}$ \\ Maria Miriam Lima da Nóbrega ${ }^{4}$
}

\begin{abstract}
This paper presents the ISO $18.104: 2003$ as an integrative model of nursing terminology. It describes the standard, studies and experiences with its use and discusses possibilities to develop knowledge in the field. The standard has been shown to be effective in developing reference terminologies, and as a standard method for interoperability and reuse. Studies have internal limitations such as language and notations unknown to nursing. Correspondence of the model with classifications used in health services and practice is incipient, which hinders its applicability and development due to the lack of examples to be analyzed and discussed.
\end{abstract}

Descriptors: Nursing; Vocabulary, Controlled; Terminology.

\footnotetext{
${ }^{1}$ RN, Ph.D. in Nursing, Professor, Pontifícia Universidade Católica do Paraná, PR, Brazil. E-mail: m.cubas@pucpr.br.

2 RN, Master's Student, Pontifícia Universidade Católica do Paraná, PR, Brazil. E-mail: adenurse@bol.com.br.

${ }^{3}$ BS in Computer Science, Ph.D. in Electrothecnical Engineering and Computer Science, Professor, Pontifícia Universidade Católica do Paraná, PR, Brazil. E-mail: malu@ppgia.pucpr.br.

${ }^{4}$ RN, Ph.D. in Nursing, Professor, Centro de Ciências da Saúde, Universidade Federal da Paraíba, PB, Brazil. E-mail: miriam@ccs.ufpb.br.
}

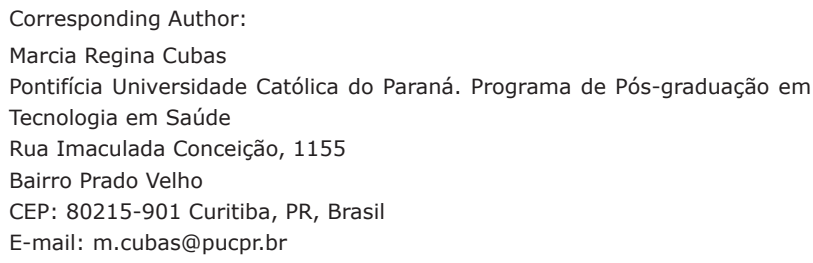




\title{
A norma ISO 18.104:2003 como modelo integrador de terminologias de enfermagem
}

Este estudo teve como objetivo apresentar a ISO 18.104:2003 como modelo integrador de terminologias de enfermagem, descrevendo a norma, pesquisas e experiências de seu uso e discutindo as possibilidades de desenvolvimento do conhecimento na área. A norma se mostra efetiva para a composição de terminologias de referência e como método padrão para a interoperabilidade e reuso. Verificou-se que as pesquisas possuem limitações internas, como linguagem e notações desconhecidas pela enfermagem. É incipiente a correspondência do modelo às classificações utilizadas nos serviços e na prática, o que impede sua análise. Considera-se que há pouca correspondência do modelo às classificações utilizadas nos serviços e na prática profissional, impedindo sua aplicabilidade e evolução, pela ausência de exemplos a serem analisados e discutidos.

Descritores: Enfermagem; Vocabulário Controlado; Terminologia.

\section{La norma ISO 18.104:2003 como modelo integrador de terminologías de enfermería}

\begin{abstract}
Este estudio tiene como objetivo presentar la ISO 18.104:2003 como modelo integrador de terminologías de enfermería; él describe la norma, investigaciones y experiencias de su uso y discute las posibilidades del desarrollo de conocimiento en el área. La norma se muestra efectiva para la composición de terminologías de referencia y como método estándar para la interoperabilidad y uso. Se verificó que las investigaciones poseen limitaciones internas, como lenguaje y notaciones desconocidas por la enfermería. Es incipiente la correspondencia del modelo con las clasificaciones utilizadas en los servicios y en la práctica, lo que impide su análisis. Se considera que hay poca correspondencia del modelo con las clasificaciones utilizadas en los servicios y en la práctica profesional, lo que impide su aplicabilidad y su evolución, por la ausencia de ejemplos a ser analizados y discutidos.
\end{abstract}

Descriptores: Enfermería; Vocabulario Controlado; Terminología.

\section{Introduction}

Several terminologies and classifications emerged in recent years aiming to standardize the representation of terms used by nursing professionals, such as: NANDA International (NANDA-I); Nursing Interventions Classification (NIC); Nursing Outcomes Classification (NOC); Clinical Care Classification (CCC); Health Community System of Omaha; and the International Classification for Nursing Practice $\left(\text { ICNP }^{\circledR}\right)^{(1)}$. This last one aims to become a unifying mark of nursing terminologies. The World Health Organization (WHO) currently acknowledges it as integrating part of the aggregate of international classifications, which comprise
The International Classification of Diseases (ICD) and International Classification of Functioning (ICF)*.

There have been five versions of the ICNP ${ }^{\circledR}$ available since 1996; however, after version 1.0 was launched in 2005(2), the classification's review and standardization were influenced by the model proposed by the International Organization for Standardization (ISO) according to ISO 18.104: 2003 - Integration of a Reference Terminology Model for Nursing(3). This model has a twofold use: it establishes criteria to evaluate classifications and, after their use, provides evidence for future review about the standardization itself.

\footnotetext{
* Available at <http://www.icn.ch/icnp_collaborations.htm>
} 
Although a unified language is needed, the standard is little known and used. In relation to classifications, besides the ICNP $^{\circledR}$, the current version of NANDA-1 2009-2011 also informs it was updated according to ISO (available from http://www.nanda.org/Home.aspx). Twenty articles were found in a search in the Pubmed, Medline and Regional Library of Medicine (BIREME) databases between 2003 and 2009. These articles were classified as theoretical, research, or experience reports in relation to the mentioned integration model.

This theoretical study presents the ISO 18:104:2003 as an integrating model of nursing terminologies. For that, it presents a brief synopsis of the content of the standard; describes research and experiences reported in the accessed articles; and discusses possibilities of developing scientific knowledge in the field.

\section{The ISO 18.104:2003}

The ISO is a non-governmental organization that has promoted a common technological language among several countries since 1947. Its standardizations are the result of consensus among experts in various fields. Its central office is in Geneva, Switzerland and its structure is composed of 157 members divided into three categories: officials, correspondents and subscripts. The first set is composed of the most representative standard institutions in countries, to the limit of one agency per country, which are allowed to participate in polls and policies of technical committees. The Brazilian Association of Technical Standards (ABTN) is the official representing member in Brazil and has more than 400 contributions to ISO $^{(3)}$.

Standardizations are developed in order to enable more efficiency and safety in the development and manufacture of products and services, and also facilitate trade, sharing of technologies, innovation and solutions to problems among countries, thereby favoring consumers, governments and world society. For standardizations to

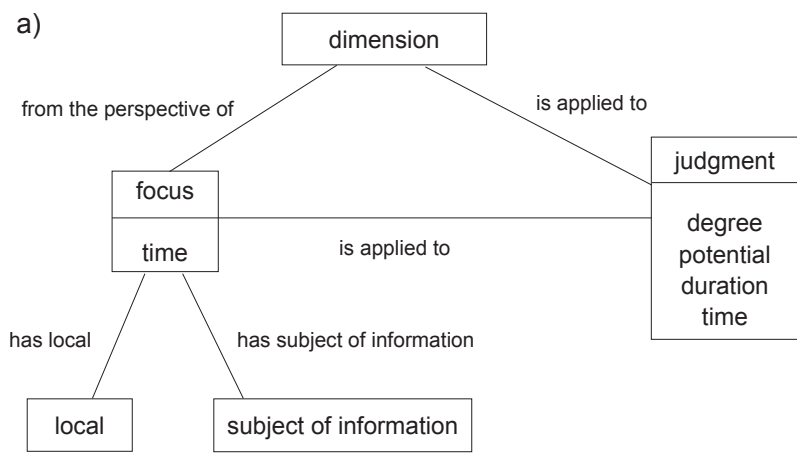

be internationally published, they should be developed by a technical committee and obtain approval from at least $75 \%$ of its official members ${ }^{(3)}$.

Before its publication, the ISO 18.104: 2003 was prepared by the Technical Committee for Health Informatics of the International Council of Nurses and by the Group of Special Interests of Nursing Informatics of the International Medical Informatics Association with the help of agencies such as the Systematized Nomenclature of Medicine (SNOMED ${ }^{\circledR}$ ) and the European Committee for Standardization (CEN), with support from the INCP ${ }^{\circledR}$ and TeleNurse ID ENTITY (Integration and Demonstration of European Nursing Terminology in Information Technology) ${ }^{(3)}$.

The creation of this standard was motivated by the need: a) to implement a computer-based system for clinical fields; b) to reimburse nursing services; c) to document nursing contributions in the results to care delivered to clients; d) to increase knowledge produced in the field(3).

The ISO 18.104:2003 emerges as a reference of representation of nursing Diagnoses and Interventions (called by the standard as Action) for potential computational processing, reflecting attempts to integrate information models and terminologies contained in other domains besides nursing. Its use proposes a model to compose terminologies through the dissection of Nursing Diagnoses and Interventions in conceptual structures, which permits mapping expressions composed of atomic concepts of different terminologies ${ }^{(3)}$.

Standardization is divided into five chapters, while the last two refer to models to develop Nursing Diagnoses and Actions (Figure 1), which are presented through a diagram of Unified Modeling Language UML. In general, it demonstrates models and describes the domain of Nursing Diagnosis and Action through a Diagram of Classes ${ }^{(4)}$, presenting Classes, Attributes of Classes and Associations among Classes. However, it is not the intention of standardization that UML diagrams are seen as the only method to model information.

b)

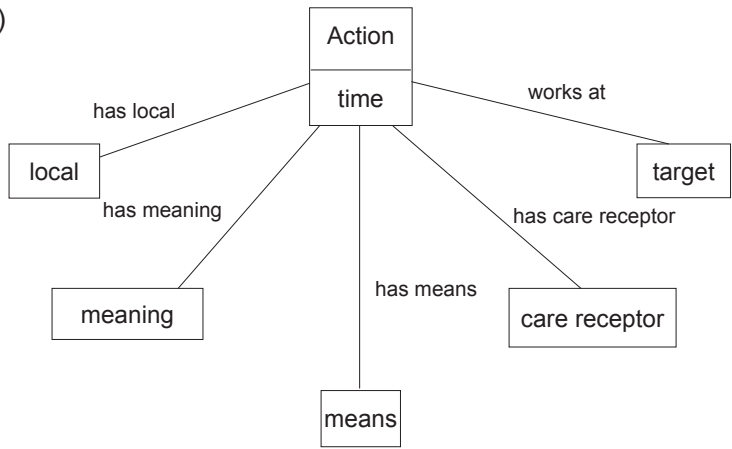

Source: Adapted from ISO 18104:2003

Figure 1 - Representation of the development of a reference model of terminology to (a) diagnoses and (b) nursing actions. 
The document makes clear that to facilitate its understanding, both to readers and professionals developing it, the use of other normative references is essential: ISO/ TS 17117:2002, Health informatics - Controlled health terminology - Structure and high-level indicators; EVN 12264:1997, Medical Informatics - Categorical structures of systems of concepts - Model for representation of semantics; and the ENV 14032:2001, Health Informatics - Systems of concepts to support nursing(3).

\section{Applicability of the model ISO 18.104: 2003}

The 18.104 has been mainly used as a basis to integrate distinct terminologies. One experience was developed at the New York Presbyterian Hospital, addressing the relationships among terms from the Home Health Care Classification and the Omaha System included in the Dictionary of Medical Entities (MED) ${ }^{(5)}$. The researchers divided the 266 Nursing Diagnoses according to the semantic categories proposed by ISO and included in the MED and concluded that, even while useful, the model is insufficient to specify nursing diagnoses concepts, indicating a need to create hierarchical structures for descriptors that instantiate semantic categories as observed in the term "Anxiety", which in NANDA-I is included in the Class "Coping Response", in the domain "Coping/Tolerance of stress" and in the INCP ${ }^{\circledR}$ is a subclass of "Emotion" and is part of the Class "Psychological Process" of the axis "Focus"(5).

A similar conclusion was reported by a study that mapped terms in nursing reports, used by the MedLee System, extracted through natural language processing and compared with semantic domains, categories and attributes of ISO 18.104. The applicability is acceptable, however, to expand the use of ISO to MedLee it is necessary to have more detail in the semantic categories $^{(6)}$.

Another possibility for generalizing the ISO for nursing diagnoses used in the Centers for Medicare and Medicaid Services (CMS) was tested extracting the expressions used by nurses in the institution from the Minimum Data Set (MDS) and dissecting them as proposed by the ISO. The result was that $100 \%$ of expressions for the domain "Focus" contained in the MDS were present in the CMS and $66 \%$ of the terms were included in the domain "Judgment". Thus, its use as a reference model of terminology was considered encouraging, enabling the promotion of a standard method for interoperability among several terminologies and also reuse(7).
Two years after publication of the ISO, a Finnish study tested the development of a terminology set to document preoperative nursing interventions through nursing records. The terms of interventions described were checked in terms of minimum requirements proposed by the standard and its use was recommended as a model to construct terminologies of reference. However, the authors indicate the need to make crosscultural adaptations for an effective interoperability among terminologies(8).

Still in relation to nursing actions, a 2006 Korean study ${ }^{(9)}$, analyzed the usability of the standard to represent the nursing actions recorded in the medical files of 545 patients of a hospital in Seoul. All the 1,209 phrases that described the nursing interventions contained words that represented "Action" and "Target" and $98.8 \%$ conclude the patient was the "Care Recipient". The authors conclude that the standard is useful but report limitations internal to the service, related to the quality of documentation and the use of different terminologies to designate actions. Hence, they suggest a larger specification of the components of the model to offer more consistency for the cross-mapping.

This study corroborates data presented by a study that evaluated the version Draft ISO $^{(10)}$, in which six attributes of the model were mapped in 21,065 nursing interventions directed to the descriptor "Pain" in the medical files of 677 patients hospitalized in an American hospital, that adapted NIC to its context. The elements "Action" and "Target" were found in $100 \%$ of phrases and $82.86 \%$ explicitly or implicitly identified the patients and "Receptor of care".

\section{Potential development of scientific knowledge}

The ISO 18.104:2003 presents among other potential uses, support for reflective nursing practice as it makes a model to construct Nursing Diagnoses and Actions available. Currently, each service realizes and documents nursing practices using diverse Theories and Classifications, adapted to its context or not, which hinders communication and integration among services, information systems and among professionals. The adoption of a reference model can be the basis to overcome difficulties, however, its mere use is not sufficient, given the described experiences, which reflect insufficiently detailed semantic categories, thereby hindering cross-mapping and, in cross-cultural adaptation, interoperability. 
On the other hand, classifications should be represented in a way similar to how they are processed and interpreted by computers, which would enable the use of computer techniques that permit not only faster cross-mapping, but also integration among classifications and other information systems.

Studies addressing semantic equivalence among classifications, adapting different terms with the same concept, oramong equal terms with different concepts, and making cross-cultural adaptations among classifications are essential for heterogeneous information systems to communicate, thereby establishing a common language for the profession.

Another gap is related to the fact that the extant classifications need an initial adaptation to the semantic domains proposed by the ISO $18.104: 2003$, which would avoid structuring terms at levels different from those in the proposed taxonomy model. After this adjustment, it is necessary to specify semantic categories contemplated in each domain to facilitate and standardize understanding of terms and to restrict ambiguous interpretations.

Despite references supporting the notion that the standard has influenced the development of some classifications organized after its publication, experience reports addressing the correlation of classifications with the ISO 18.104:2003 were not found, only its application in nursing records and interoperability among different records with a multiprofessional basis. It is worth noting that the lack of Brazilian publications in this field reveals a gap in the production of knowledge in this domain, both in international and national terms.

Criteria presented in the diagrams of classes of Nursing Diagnoses are not identified in the INCP ${ }^{\circledR} 1.0$. For instance, in the classification "Potential" a subclass of "State" is considered, which in turn is a subclass of the Axis "Judgment", while in the ISO, "Potential" is an attribute of the class "Judgment". Therefore, the concern of researchers who assert the need to establish a detailed hierarchy is warranted.

Since the INCP $^{\circledR}$ is part of the WHO Family of Classifications, it is crucial to make the criteria used in its development available, as well as how it is represented, making the use or lack of use of the ISO clear. This knowledge will encourage research capable of proposing the adequacy of INCP $^{\circledR}$ to ISO or an adjustment of the ISO model to increase its potential for use.

\section{Final Considerations}

The ISO $18.104: 2003$ is seen from the perspective of an integrative model because it establishes standards for nursing terminologies to be used in computer systems. However, even though the model has been available since 2003, few studies focused on this subject, which indicates there is only an incipient development of knowledge in the field. Given this manuscript, some hypotheses are raised to explain, at least in part, this deficiency. The models presented in the articles, as well as in the ISO, are in language and notation unknown to nursing professionals. Consequently, the represented models can lead to distinctive interpretations, without a consensus of what the language and notation really represent, which leads to misinterpretation and inappropriate use. This difficulty might be overcome by an effective integration among professionals in the health and computer fields, strengthening the dissemination of technical-scientific knowledge.

Another issue to consider is the weak correspondence of the model to the classifications used in health services and professional practice, which hinders both its applicability and development due to the absence of practical examples to be analyzed and discussed.

\section{References}

1. Nóbrega MML, Garcia TR, Furtado LG, Albuquerque CC, Lima CLH. Terminologias de enfermagem: da taxonomia da NANDA a classificação internacional para a prática de enfermagem. Rev Enferm UFPE [online] 2008 [acesso em: 02 fev 2009]; 2(4): 390-6. Disponível em: http://www.ufpe.br/revistaenfermagem/ index.php/enfermagem/article/viewPDFInterstitial/176/214

2. Conselho Internacional de Enfermagem. Classificação Internacional das Práticas de Enfermagem: versão 1.0. São Paulo (SP): Algol; 2007.

3. International Organization for Standardization. Health informatics: integration of a reference terminology model for nursing: ISO 18104. Geneva (Switzerland) 2003 [cited 2008 Ago 5] Available from: http://www.iso.org/iso/iso_catalogue/ catalogue_tc/catalogue_detail.htm?csnumber $=33309$
4. Rumbaugh J, Blaha M. Object-Oriented Modeling and Design with UML. 2 ${ }^{\text {a }}$ ed. New York: Prentice Hall; 2004.

5. Hwang J, Cimino JJ, Bakken S. Integrating nursing diagnostic concepts into the medical entities dictionary using the ISO reference terminology model for nursing diagnosis. J Am Med Inform Assoc. 2003; 10:382-8.

6. Bakken S, Hyun S, Friedman C, Johnson SB. ISO reference terminology models for nursing: applicability for natural language processing of nursing narratives. Int J Med Informatics. 2005; 74(6):615-22.

7. Harris M, Kim H, Rhudy L, Savovo G, Chute C. Testing the generalizability of the ISO model for nursing diagnoses. AMIA Annu Symp Proc 2003 [online] ; 2003 [cited 2008 Sep 17]:274-8. Available from: http://www.pubmedcentral.nih.gov/ artclerender.fcgi?tool=pubmed\&pubmedid $=14728177$ 
8. Junttila K, Salantera S, Hupli M. Developing terminology for documenting perioperative nursing interventions. Int $\mathrm{J}$ Med Informatics. 2005; 74(6):461-71.

9. Hwang J, Hyeoun-Ae P. Exploring the usability of the ISO reference terminology model for nursing actions in representing oriental nursing actions. Int J Med Informatics. 2009; [online]; [cited 2009 Jun 01]. Available from: http://www.sciencedirect. com/science?_ob=ArticleURL\&_udi=B6T7S-4WDFCGS-1\&_ user $=5479910 \& \_r d o c=1 \& \_f m t=\& \_o r i g=$ search\&_sort $=d \&$ _ docanchor $=\&$ view $=c \& \_$_acct $=C 000067466 \&$ _version $=1 \&$ _ urlVersion $=0 \&$ \&userid $=5479910 \& \mathrm{md} 5=4577205 \mathrm{f7f6e} 6 \mathrm{~b} 708806$ 1 a1a68599189
10. Moss J, Coenen A, Mills ME. Evaluation of the draft international standard for a reference terminology model for nursing actions. Int J Med Informatics 2003; [online] ; 2003 [cited 2009 Jun 01] 36(4):271-8. Available from: http://www. ingentaconnect.com/content/els/15320464/2003/00000036/00 000004/art00087 